\title{
Book-Collecting and Literature in Eighteenth-Century Britain
}

If Dr Johnson's assertions that he lived during the "age of authors" and that Britain was "a nation of readers" were to become emblematic of the literary culture of the eighteenth century, a further claim that he omitted to make was that his was also an era of book-collecting. ${ }^{1}$ It would certainly have been no exaggeration. Indeed it would have said much worth knowing about Johnson's world and what it valued. For from the great libraries of the wealthy and the well-connected, like those accumulated towards the end of the century by the Prime Minister's son Horace Walpole (today the focus of one of the major on-going reconstructive projects) and by Richard Hurd, the scholarly and urbane Bishop of Worcester (which survives virtually intact at Hartlebury), to the long-lost results of many anonymous Georgian men and women who modestly encapsulated James Thomson's exuberant suggestion that life's "matchless joys" comprised "Retirement, rural Quiet, Friendship, Books", the ownership of printed texts was a feature of eighteenth-century existence for immense numbers of Britons from many different backgrounds and most social classes. ${ }^{2}$ This in turn helps explain why the size and character of the resulting collections so frequently attracted comment from astute observers at the time-positively, for example, by Johnson himself, when he claimed while travelling in the remote Hebridean islands in 1773 that, on the strength of his lairdly hosts' extensive collections, "it was one of the remarkable things of Skye, that there were so many books in it", but also sometimes less favourably, as, for instance, from the novelist Tobias Smollett, openly contemptuous in dismissing the culture of Provence as a "total blank" and the region as "devoid of taste and literature" precisely because of there being "no public nor private libraries that afford anything worth perusing" for the inquisitive British tourist. ${ }^{3}$ The present essay takes this intense awareness of the significance of collections of books in this period as its initial point of departure. It begins by assessing the evidence for book-collecting as a cultural practice in eighteenth-century Britain before also going on to explore how the physical acquisition and ownership of printed texts interacted with the development of contemporary literary culture and indeed with the history of English literature as a whole.

Book lists, book-buyers and bibliomaniacs

Any investigation which takes the eighteenth-century British book collection as its primary focus must necessarily sooner or later become an exercise in the study of book lists. Not least this is because documents recording the possession of printed texts were generated in very substantial quantities in the Georgian period and large numbers are still extant. Whether a practical guide 
created to help a collection's owner to find and monitor individual titles (particularly in circumstances where these were unusually numerous or other people were borrowing them) or else simply a one-off inventory or auction catalogue prepared at the moment of final dispersal (mostly triggered by the owner's death or, not infrequently, by bankruptcy), these lists capture with reassuring precision a picture of the books which belonged to an identifiable person at a specific point in historical time. Unfortunately, however, they also tell us rather less about book-collecting as such than might appear at first glance. Horace Walpole, no less, vividly illustrates the danger of inferring too much from such sources. For while we know which books he possessed it is far from obvious that he had either chosen all of them himself or even that he particularly liked them. ${ }^{4}$ After all, his library contained the Annals of Scotland by the Scottish historian Sir David Dalrymple, Lord Hailes, in a copy actually gifted by the author when the first volume appeared in 1776 . Worse, while Walpole had dutifully worked his way through it, we know in this case that he disliked it intensely since what he took to be its violent Tory prejudices provoked him to add a series of hostile Whiggish annotations to its pristine pages. ${ }^{5}$ None of this, however, stopped Walpole from keeping this fine autographed presentation copy of the Annals in his collection, and nor should this surprise us. As Sydney Smith also quipped, neatly underlining that in late Georgian Britain printed works were prestigious objets for conspicuous display and that owning them most definitely did not always entail their active consumption by a reader, let alone endorsement, there did indeed often seem to be "no furniture so charming as books".

The surviving evidence for household or family libraries poses even more serious interpretative problems for anyone interested in the habit of book-collecting. For because printed texts were also valuable property handed down between the generations, the eighteenth-century owner of an older book as documented by an extant inventory or catalogue (like the one kept by the Cumberland gentleman Henry Dalton with the revealing title "A List of Books Which I Got From My Wife's Share of Her Mother Palmer's Library") might well never have taken it down off a dusty shelf, never mind approved of its burden. ${ }^{7}$ At the same time the nature of heritable property ordinarily descending under primogeniture also meant that documentary records tended by default to ascribe ownership to men even where female family members might in practice have been the most frequent users, even the original acquirers, of certain books. Further opaqueness arises from the professional booksellers' habit of consolidating the libraries of several different individuals for convenient disposal in a single large auction: thus we can safely say that at his premises at Gray's Inn in 1753 the bookseller Thomas Osborne was offering copies of modern literary classics like Gulliver's Travels and Tom Jones as well as a copy of the early English text The Chastising of God's Children printed by either Caxton or Wynkyn de Worde, all clearly procured from their recently-deceased owners, but 
the slightly impatient title that Osborne gave to the resulting list-A Catalogue of the Libraries of the Late Dr. Cromwell Mortimer, Secretary to the Royal Society, Edmund Pargiter, Esq; and Many Others, Too Tedious to Mention; All Purchased This Last Summer-merely confirms that we cannot realistically hope to link any of these titles securely to a specific contemporary collector. ${ }^{8}$

One more feature of the book list as purported evidence of eighteenth-century collecting - the fact that it provides only a single snapshot of ownership-also makes it all but impossible for us in practice to reconstruct a given collection's internal history over time. At Calgarth Park in Westmorland, for example, the library begun by Richard Watson, Bishop of Llandaff from 1782, was later catalogued, a process which allows us to confirm that it eventually included all of Sir Walter Scott's novels with the single exception of Heart of Midlothian. But by which member of the Watson family these books were actually selected and bought (the prelate himself died in 1816, less than two years after Scott's momentous series began), and whether the missing item had ever been present at Calgarth or had for some reason never been purchased in the first place, it is now not possible to say. ${ }^{9}$ If we note also that some of the more substantial collections were frequently spread between several residences, each catalogued separately, and that we can therefore only hope to identify a proportion of what must actually have been owned by one person-while for some, like Watson's near-neighbour beside Lake Windermere, Sir Michael le Fleming, in 1803, we only possess a surviving catalogue for the books kept in certain rooms in a large family home-the magnitude of the problem in treating these documents straightforwardly as comprehensive and precise evidence not only of book-collecting but also of the purchasing habits, reading practices and wider cultural and intellectual preferences of identifiable eighteenth-century individuals becomes only too obvious. ${ }^{10}$

Despite these grave limitations, however, book lists of one sort or another have underpinned many important recent studies in literary and intellectual history-chiefly in the absence of any other insights, beyond a few stray surviving texts with robust provenance and the sort of random anecdotal references found intermittently in letters and commonplace books, into what people might actually have bought and read in the past. A classic instance of a list-based study pertaining to the eighteenth-century anglophone world is David Lundberg and Henry F. May's seminal investigation of the impact of Enlightenment culture in late-colonial America which sought to probe the ideological origins of the coming Revolution by reconstructing the contents of contemporary book collections. ${ }^{11}$ Similar studies of catalogues and inventories of various descriptions have also made important contributions to our knowledge of historical phenomena such as widening literacy, changing social structure and transformational religious experience in Spain, England and Germany 
between the Reformation and the Enlightenment. ${ }^{12}$ Because of such work we now have a comparatively sophisticated understanding of how widely printed books were distributed in the early modern period, a particular outcome of which in recent years has been unprecedented appreciation of just how many relatively humble individuals may actually have been in a position to join the ranks of the book-owning population by virtue of acquiring even a relatively small number of titles.

This latter trend, increasingly obvious in Britain in particular by the eighteenth century, seems to have come about because of a combination of expanding print-runs, falling production costs and rising real incomes. These factors meant that collecting at least a few texts was finally becoming feasible even for substantial numbers of quite poor men and women: George Bowden, for example, a Taunton shoemaker in the early 1760s, apparently owned seven (described as "a school-size Bible, Watt's Psalms and Hymns, Foot's Tract on Baptism, Culpepper's Herbal, the History of the Gentle Craft, an old imperfect volume of Receipts in Physic, Surgery, \&c. and the Ready Reckoner"), while William Barnard, a tenant farmer on the estate of the $5^{\text {th }}$ Earl of Guilford at Harlow Bury near Chelmsford in Essex at the turn of the nineteenth century, possessed twenty-one whose titles he duly recorded on the inside back-cover of his journal. ${ }^{13}$ Such collections, especially on this very limited scale, were unlikely to have been brought together without serious motivation and significant sacrifices-as Richard Altick suggested, a Georgian merchant's clerk on a fairly typical income of a few shillings per week would have had "to choose between buying a newly published quarto volume and a good pair of breeches.... or between a volume of essays and a month's supply of tea and sugar". ${ }^{14}$ But across Britain in the eighteenth century such basic economic calculations were plainly being made, and book-collecting of a kind was emerging as a result, in the lives of more and more individuals from ever more diverse social and occupational backgrounds.

At the other extreme, some British collectors by the end of the period, benefitting from exactly the same underlying processes of increasing availability and affordability but clearly unrestrained by meaningful financial considerations, eventually owned not merely thousands but tens and even occasionally hundreds of thousands of volumes. ${ }^{15}$ Although the now-familiar label "bibliophile" entered common English usage only in the next century following the publication of Thomas Frognall Dibdin's The Library Companion in 1824, the striking phenomenon of the exceptionally large personal book collection, and the associated idea that it might in fact be the outward manifestation of a chronic obsessive-compulsive disorder, was becoming well-known through the previous hundred years, and the resulting neologism "bibliomania", probably deriving from its French equivalent, certainly had early Georgian currency-the antiquarian Thomas Hearne, for example, 
worrying to his diary in 1734 that his imprudent spending on books might mean he was "touched with Bibliomania" while the $4^{\text {th }}$ Earl of Chesterfield wisely cautioned his son in 1750 to "Beware of the Bibliomanie". ${ }^{16}$ By later in the century more of Britain's richest men were exhibiting the tell-tale symptoms. Topham Beauclerk, great-grandson of Charles II and friend of Johnson, is a fine example of what could happen when money really was no object, with his extraordinary personal library building on Great Russell Street in London, reputedly modelled on a design by Robert Adam, which apparently cost its proud owner $£ 2,200$ to construct: “...it reaches halfway to Highgate. Everybody goes to see it", claimed Walpole, clearly envious as well as sarcastic. ${ }^{17}$ Beauclerk's collection, catalogued for auction following his death in 1780 , ran to nine thousand titles in more than thirty thousand volumes. ${ }^{18}$ Nor was even this the practicable upper limit to the consequences of incurable bibliomania by the turn of the nineteenth century when a susceptible individual also had access to effectively limitless quantities of disposable income: Richard Heber, politician and book-collector, was reliably said to have spent $£ 180,000$ of his family's landed fortune in accumulating almost 150,000 volumes which he kept not just at his several English homes but also in Paris, Ghent, Brussels and Antwerp as well as in the Netherlands and Germany (though, in another nice Smith-like hint about the complex relationship that always existed, especially with the grandest collections, between owning books and actually reading them, Heber also reputedly asserted that "No gentleman can be without three copies of a book; one for show, one for use, and one for borrowers"). ${ }^{19}$

\section{"A library for use, rather than ostentation"?}

The book collections that resulted in eighteenth-century Britain not only ranged widely from the meagre handful on a single shelf or in a small trunk kept by people like George Bowden to the extravagant cornucopia spread across many houses and several different countries owned by singular eccentrics like Richard Heber. They also fell broadly into a number of further categories essentially depending upon the circumstances, needs and interests of their individual owners. One type that will always require separate consideration is, of course, the artfully-constructed book collection which, partly because of what was often its sheer size and partly also because of its unusual internal composition, was rarely brought together with active reading and regular use primarily in mind-the collection, in other words, of the so-called "book man" of old, the potential bibliomaniac of the Georgian era, for whom owning and being able to display a body of printed texts as precious and prestigious objects was in and of itself the over-riding concern. Because of the costs involved these collections were never very numerous but their creators included, as we have already 
seen, some of the most prolific purchasers of the age: Heber, for example, as well as being noteworthy for the extraordinary physical scale of his collection, far beyond what anyone could ever in practice hope to read their way through, also invested heavily in early English literature in particular and eventually managed to bring together a quite exceptional concentration of both insular and Continental incunabula (359 of them formerly owned by Heber now reside in the Bodleian Library alone). ${ }^{20} \mathrm{~A}$ comparable pattern of impressive antiquarian acquisitions on a necessarily less ambitious scale, again informed by special interest in the history of authorship and printing technologies and driven by an insatiable desire for valuable and rare items as such, can also be found elsewhere among the wealthier collectors-and from early in the century, since incunabula were already an especially prized acquisition even for the devoted book-lover in Queen Anne's time. The Inner Temple barrister Draper Donynge, for example, a collector of many sixteenth-century publications, owned the celebrated 1499 Paris edition of Isidore of Seville's Etymologiae at his death in 1711, while the London doctor Charles Bernard who died in the same year owned the 1500 edition of Virgil's complete works (also printed at Paris), the 1498 edition of Poliziano's works produced at Venice by Aldus Manutius and the 1488 Augsburg edition of Johannes Angelus's Astrolabium..$^{21}$

Clearly, then, the peculiar obsessions that gave rise to what contemporaries would increasingly diagnose as bibliomania sometimes resulted in a collection with a distinctive complexion, marked out from most others by its emphasis upon its earlier, scarcer or merely exceptionally expensive component parts. Indeed antiquarian tendencies of this particular kind did not escape the hostile attentions of certain eighteenth-century moralists who, like Vicesimus Knox in the 1790s, cautioned against aspiring to own "a very large or very curious collection of books" and explicitly favoured the building of "a library for use, rather than ostentation". ${ }^{22}$ Yet the purchasing of books purely for practical scholarly and intellectual purposes along the lines suggested by Knox, especially with the owner's professional or vocational requirements to the fore, could also lend some collections a peculiar flavour all of their own. Charles Bernard, for example, had large holdings of medical and scientific literature that obviously cannot be divorced from his duties as the Queen's surgeon. So too many decades later did Robert Hamilton, the notable Scottish physician who practiced at King's Lynn in Norfolk and who died in 1793: when the local bookseller Richard Marshall oversaw the sale of Hamilton's books the catalogue grouped 391 of the 578 titles (that is, approaching $70 \%$ of the total) either under the self-explanatory heading "Physic, Surgery, Anatomy, Natural History \&c." or else described them simply as "Medical". ${ }^{23}$ More typically for medical men, however, their occupational concerns exerted a discernible skew on their book collections even as their general interest in literature and books led them also to range rather more widely in what they bought. A good 
example from the middle of the century would be the prominent London physician Robert Nesbitt who died in 1761 and whose library was disposed of by the bookseller Samuel Paterson on Essex Street at a series of public auctions held on several evenings in late July and early August that year. Although Nesbitt had acquired a significant number of early sixteenth-century classical texts, the sale catalogue nevertheless specifically emphasised that the lots had strength "more especially in the Arts of Medicine, Surgery, Anatomy, Midwifery, and in various Branches of Natural History". ${ }^{24}$

Perhaps an even more interesting example is provided by the London physician Abraham Hall, a collector who eventually owned nearly 12,000 titles. When they were auctioned following his death in 1752 they included not only a great number of medical texts and a range of incunabula but also a wide selection of modern imaginative literature-including the recently-published Tom Jones in a 1750 edition, the novels of Aphra Behn, Dryden's plays and a couple of editions of Swift's Tale of a Tub-which it is clearly impossible to relate in any way to his immediate professional concerns. ${ }^{25}$ Bookish lawyers also often displayed the same mixed motives as Hall, their textual choices obviously influenced by but not restricted to their vocational preoccupations. Thomas Baynham, for example, a barrister of the Inner Temple who died in 1783, left over 6,000 works which included in excess of 400 legal titles-more than most non-lawyers, to be sure, but still, at just $7 \%$ of the total, scarcely dominating such a large and diverse collection encompassing every field of literature. ${ }^{26} \mathrm{~A}$ similar collecting trajectory, but in some ways even more intriguing, was described by the wide-ranging book purchases of James Wright, who died in 1719. A genuine polymath by professional function as well as by intellectual inclination, Wright was a barrister at the Middle Temple as well as a practising physician and his book-buying fully reflected this versatility: his personal library of 1,446 titles, though clearly quite conservative in scale, had unsurprising strength in what the cataloguer of the final sale glossed as "Cannon and Civil Law", but it was also rich in historical, topographical, classical and modern literature-everything from Ovid's Metamorphoses to Camden's Britannia, from Paradise Lost to Livy, the generalist staples for any educated man of the period. ${ }^{27}$

Like the lawyers and doctors, clergymen again frequently amassed book collections that were biased to some extent towards the types of literature they required for professional purposes. When the library of the late William Newcome, Archbishop of Armagh, was sold off in Dublin in 1800, for example, 1209 of the 3079 titles (or 40\%) were classified as "Divinity" by the auctioneer James Vallance, a similar case to that of the Non-juring bishop George Hickes almost a century earlier, whose death in 1715 had released onto London's second-hand market an outstanding collection of several hundred titles, many in Latin and the clear majority steeped in religious learning. ${ }^{28}$ On a slightly smaller scale the collection of just 800 titles built up by Revd John Jackson of Leicester, finally 
dispersed on his death in 1764, contained, as well as a sprinkling of incunabula (Aldine editions printed at Venice were a particular favourite), a substantial body of important theological literature, ecclesiastical histories and religious polemic. ${ }^{29}$ Jackson's book collection was perhaps typical of the eighteenth-century clergyman both in size and in internal composition. It certainly bears close comparison with the libraries of other men of the cloth like the Revd Jeremiah Hunt, the Independent minister at Pinners' Hall in London who died in 1744, the Revd John Gill, the Baptist pastor in Southwark who died in 1772, and the Revd Thomas Everson, the Anglican rector of Thetford in Norfolk, who died in 1749, all three of whom eventually owned approximately five hundred works all told, overwhelmingly scholarly in nature and mostly in the fields of church history, sermons and theology. ${ }^{30}$ These churchmen were clearly the kind of book collector, and probably also the type of reader, who brought together significant though not very substantial personal libraries with an unmistakable and easily explicable religious bias. Indeed they were men who, in an age initially notorious for what Richard Baxter had called "polemical divinity" and then marked by rising evangelicalism at least as much as it was ever characterised by the spread of Enlightenment and the entrenchment of secular values, always formed a particularly important segment of the contemporary book-buying market-a reliable customer base of pious and learned gentlemen which actually sustained the publication of so much new religious literature in Britain as well as the continuing circulation of so many old studies in similar vein. ${ }^{31}$

Even when the particular contents of book collections were not obviously connected with a requirement for specifically vocational forms of knowledge, however, they still often illuminated the peculiar intellectual preoccupations of those who owned them. Two such examples are the private libraries of Samuel Gale and Thomas Martin, both of them enthusiastic antiquarians, their interests in early printed books, British topography, historiography and classical literature as well as medals and coins lavishly documented in the respective final sale catalogues for their collections from 1754 and $1774 .^{32}$ Both men were also clearly prosperous gentlemen with the time and resources to be able to immerse themselves in the literature that fascinated them. Sir Christopher Wren, who died in 1723 , is another example of a book-collector for whom the surviving sale catalogue-notable, as one recent scholar has said, for the "extreme paucity of scientific books" and yawning gaps in the architectural literature-hints at reading tastes driven by sheer intellectual curiosity and largely unconnected with specifically vocational interests. ${ }^{33} \mathrm{~A}$ quite different insight into the motives of an individual book-owner, however, and from the other end of the social spectrum, comes from a document entitled "A Catalogue of Books belonging to M. Cowgill". Its creator, one Mary Cowgill, lived somewhere in Ribblesdale in the West Riding of Yorkshire at the turn of the nineteenth century, and this intimate record of her own small collection of a few dozen titles, containing many 
religious items such as "Family Bible \& Testament", The Pilgrim's Progress, The Whole Duty of Man and John Wesley's Collection of Hymns, reveals her as a committed Christian, probably a Methodist, whose engagement with the devotional literature she owned must in some way have helped articulate and reinforce her inner spiritual life. ${ }^{34}$ Different yet again was the actor John Kemble whose passion for imaginative literature is confirmed by the sale catalogue of that part of his book collection which went under the hammer in London in 1821 when he had retired and was living in Switzerland. Alongside the classic eighteenth-century novels like Richardson's Pamela and Burney's Cecilia and work by both Sterne and Fielding was Scott's Rob Roy, a recently-published book which Kemble can only lately have acquired, all of these titles gesturing at a man whose collecting, and perhaps whose reading tastes, very much embraced the contemporary fashion for narrative fiction. ${ }^{35}$

Criticism, canonicity and the creation of English literature

The incidence of best-selling novels in collections like those of John Kemble is a reminder that bookbuying in this period, even where professional responsibilities had not entailed a pronounced emphasis upon certain forms of specialist literature, was a considered and therefore highly structured activity. Indeed eighteenth-century Britons were subjected to a positive barrage of explicit advice and instruction on book-selection which inevitably had implications for their decisions as book-collectors. Some of this guidance directly reflected the issues we have been considering, revolving around the putative suitability of certain types of book for a collector's personal circumstances. The German writer Jacob Friedrich Bielfeld, for example, whose L'Érudition Universelle, first published in 1768, was quickly translated into English, insisted that for many a reader "It is very natural for a principal part of his library to consist of books relative to his profession or his favourite study. Thus a prince's library should contain the best authors on politics; and that of a man of literature of the most celebrated critics." Nonetheless, as Bielfeld was clearly aware, considerations of taste and fashion might well also need to be accommodated, a factor that he believed had if anything only become even more important in recent times. As he remarked, "a bibliotheque, which appeared very complete at the beginning of this century, is very far from being so now. Whoever would collect a judicious and useful library, should certainly consult the best journalists, and endeavour to select such works as appear the most excellent in the republic of letters, and consequently his library, will increase as long as he lives" ${ }^{36}$ Collecting books, in other words, especially in an age of rapidly expanding printing and publication, increasingly involved paying due attention to expert advice so as to form the sort of library that would meet the standards set by right-thinking opinion. 
In eighteenth-century Britain, where criticism both as a ubiquitous intellectual tool and as a popular literary form in its own right was developing with particular speed, this gave rise to constant attempts to guide the hand of anyone who might wish to purchase printed texts. Dominant critical arbiters like Johnson and Hugh Blair whose opinions could make or break fledgling literary careers, earnest writers of educational advice-books like John Aikin and Thomas Sheridan, innumerable anonymous commentators in periodicals like the Critical Review and the Monthly Review who passed publicity-generating instant judgment on new publications and more considered academic specialists like Thomas Warton whose writings disseminated the claim that there existed a canon of superior works of native genius-Shakespeare, Milton, Pope and the rest-that increasingly came to be accepted as defining "English literature" in a serious sense, all contributed to this burgeoning movement. ${ }^{37}$ That the public might actually resist such formidable authority seemed inconceivable for, as Aikin averred, only an appropriate selection of books had the potential to provide access to "the choicest thoughts of the ablest men in their best dress", while what William Godwin called "a methodical and persevering course of reading", a notion which necessarily implied a judicious and well-informed choice of texts, was widely believed to be essential for personal development. ${ }^{38}$ Unsurprisingly some exponents took critical discrimination to its logical conclusion and simply listed the particular works which in their opinion needed at least to be known and ideally to be acquired. John Whiston, for example, a London bookseller with an obvious commercial interest in attempting to steer the book-buying public towards certain purchases, issued A Catalogue of the Most Esteemed and Useful English Books, Proper to Form a Select Library in 1758, a didactic tome which provided what he elsewhere called "some directions in the choice of proper Authors, on the several subjects which would improve the understanding and correct the judgment, as well as please the imagination at the same time". ${ }^{39}$

It should therefore be no surprise that many of the more substantial collections documented by surviving book lists seem broadly to follow the suggestions made by Whiston. Proposing 89 separate works categorised as "Geography, Chronology, History of Foreign Countries, Voyages and Travels" and a further 99 with the same thematic range but a specifically British focus, Whiston in effect encouraged the building of a collection in which the largest single group of texts ( $40 \%$ of the total) would be topographical or historical in character. The remainder of Whiston's proposals comprised nine antiquarian works, twelve dictionaries, 31 classical texts in translation, 38 scientific titles ("Mathematicks, Astronomy, Agriculture, Gardening, Physic", as he called them), 18 on art and architecture, 37 on "Divinity", 53 poetry and plays and 87 more simply attributed to "Miscellaneous Authors" (the latter incorporating a mixture of legal and philosophical works, journalism, essays and novels). This was a pattern very often replicated in practice by those building contemporary book 
collections and there is every reason to suppose that Whiston was accurately reflecting widely-held assumptions about the literary composition of a respectable mid-eighteenth-century library. Certainly one sees them mirrored in the period's institutionalised lending collections-as, for example, at the turn of the nineteenth century at Lancaster where $37 \%$ of the books acquired by the proprietors of the Amicable Society Library were historical or topographical in nature, and again at the Bristol Library Society where $35 \%$ of recorded borrowings by members in the 1770 s and 1780 s fell into this same category. ${ }^{40}$ Personal book collections frequently followed in the same direction. A sale catalogue published at Norwich in 1753 , for example, which advertised the contents of the libraries of four recently-deceased men-two local parish clergymen, a physician and a Cambridge divine-painted a familiar picture of their collective holdings: although there was the predictable strong bias towards religious literature (53\%) attributable to the vocations of three of the men, the books classified as "History, Antiquities, Voyages, Travels" nonetheless represented by far the largest other category with 988 (or 30\%) of the 3,264 books auctioned by William Chase. ${ }^{41}$ The same trend is seen in the combined collections of Revd Adam Batty of St Johns, Clerkenwell, and an unnamed bishop, sold from Gyles Fletcher's bookshop in Holborn in 1738: here, despite the two men's professional leanings, the historical and topographical literature still accounted for approximately one-third of the books listed. ${ }^{42}$

Whiston's ideas about what was now emerging as "English literature" were equally representative of mainstream opinion. This increasingly maintained that there existed a particular set of imaginative works of "national" significance, old as well as new, with which contemporary British book-lovers needed to be familiar - a tendency reinforced by the landmark copyright case of 1774 which finally confirmed that older texts could indeed be freely reprinted by any enterprising bookseller. ${ }^{43}$ In fact, in the "Poetry and Dramatick Authors" section of Whiston's Catalogue, unlike elsewhere, the titles were arranged in chronological order, a presentational device that clearly embodied the notion of a continuously evolving English literary canon down the ages which conferred special status and legitimacy upon its constituent texts-beginning with "Chaucer's Works, by Urry", "Spenser's Faerie Queen, and other Works, by Hughes" and "Shakespear, by Theobald", progressing through Jonson and Milton to the Civil War-era highlights of "Cowley's Works" and "Waller's Poems and Life, by Fenton" and on to the Restoration with Butler's Hudibras and Dryden's poems before ending with the modern British classics, recent candidates for future canonisation, like "Gay's Poems and Fables", "Thomson's Seasons, and other Works", "Pope's Works, by Warburton”, “Akenside's Pleasures of Imagination" and "Dodsley's Collection of Poems". ${ }^{44}$ Again this kind of pattern was closely followed by many book-collectors, as much because of shared values and common ideas about literary culture as because they were acting under specific instruction from Whiston and his 
ilk. One anonymous collector whose books were sold in 1768, identified by the sale catalogue from Samuel Paterson on The Strand simply as "A Gentleman Who is Gone Abroad", owned fewer than 800 titles but they included all of these suggestions apart from Akenside and Dodsley, generally in the form of one or more editions of each poet's collected works. ${ }^{45}$ The same two exceptions apart, these titles were again found in the collection offered for sale in London in 1786 which largely comprised the holdings of Anthony Purver, the Quaker autodidact and biblical translator. ${ }^{46}$ Yet another large sale dominated by the legal texts owned by the bookseller and printer John Millan and auctioned in 1784 by his successors Thomas and John Egerton similarly included all of these examples of literary works recommended by Whiston, Dodsley's excepted. ${ }^{47}$

That criticism and authoritative guidance would not always be the decisive influence in bookcollecting, however, was inevitable. And nor was this fact unacknowledged by contemporaries. After all, it was undeniable that fashions and tastes could change, not only in society at large but also in each individual: as the educationist John Mason observed in 1778, "A Scholar that has been all his Life collecting Books, will find in his Library at last a great deal of Rubbish. And as his Taste alters, and his Judgment improves, he will throw out a great many as Trash and Lumber... ". ${ }^{48}$ It therefore followed that book-collecting, just like reading, could sometimes be at odds with current critical opinion. Nowhere was this truer, moreover, than in the case of narrative fiction, the most contentious literary form of the age. Whiston, motivated as always by primarily commercial considerations, certainly did not ignore it. Indeed, his list of recommended acquisitions for a model book collection was emphatically broad-minded, including under the heading "Miscellaneous Authors" such challenging but also popular and therefore potentially lucrative suggestions as Machiavelli's works and Mandeville's Fable of the Bees. This is surely why he also proposed a number of titles drawn from the controversial domain of prose fiction, including not just older foreign classics like Don Quixote and The Arabian Nights, already built into in the emerging canon, but also modern English offerings such as the novels of Fielding, Smollett and Richardson as well as the collected works of Penelope Aubin and Eliza Haywood. ${ }^{49}$

Yet as Whiston well knew, recommendations of this kind were not unproblematic. Many influential British critics roundly condemned the novel as a genre and warned readers of the grave dangers it posed. Knox, for example, claimed in 1778 that "If it be true that the present age is more corrupt than the preceding, the great multiplication of Novels has probably contributed to its degeneracy", while Coleridge would soon excoriate the effects of narrative fiction on the intellect and sensibilities of the individual reader: 
Where the reading of novels prevails as a habit, it occasions in time the entire destruction of the powers of the mind; it is such an utter loss to the reader, that it is not so much to be called pass-time as kill-time. It conveys no trustworthy information as to facts; it produces no improvement of the intellect, but fills the mind with a mawkish and morbid sensibility, which is directly hostile to the cultivation, invigoration and enlargement of the nobler faculties of understanding..$^{50}$

In such a climate, caught between the pecuniary motives of booksellers with an interest in selling narrative fiction to the public and the blood-curdling Jeremiads of critics bent on protecting them from its supposedly baleful effects, the reader faced difficult choices when navigating his or her pathway through the growing profusion of novels available for sale or for rent.

To the book-collector who was also the user of institutionalised lending collections, the same problem about the status and function of the novel as "literature", a question framed in ethical as much as in aesthetic terms, would have been familiar in a slightly different context. On the one hand the rapidly increasing availability of narrative fiction was indissolubly linked in the eighteenthcentury imagination with the activities of the profit-oriented circulating libraries which were inevitably more interested in providing what readers really wanted than in reflecting and imposing critical obiter dicta - the result being "that common herd of Novels (wretched offspring of circulating libraries)", as the Scottish novelist Henry Mackenzie called them. ${ }^{51}$ On the other hand the membership-based subscription libraries, like those at Lancaster and in Bristol which, as we have already seen, developed strong core holdings in historical and topographical literature, were more swayed in their collection-building by aspirations to the attainment of polite respectability and the exercise of moral responsibility. Accordingly their members, who were also the owners of their stock, were generally more reluctant than circulating library proprietors to invest heavily in texts with such questionable qualities - and thus in recent popular novels in particular: as these reservations were crystallised in the Leicester Literary Society's rulebook in 1790, "No Novel, or Play shall be admitted into the Library, but such as have stood the test of time, and are of established reputation".$^{52}$ And yet, as the lengthy caveat in this regulation hints, narrative fiction nonetheless formed an important part of many subscription libraries' collections. Novels amounted to the second-largest single category in the catalogue of the Shrewsbury Subscription Library by the early nineteenth century while at Bristol the eighth-most-borrowed item in the entire collection through the 1770s and 1780s was none other than Tristram Shandy, the most talked-about novel of the age. ${ }^{53}$ Unsurprisingly, then, the same pattern of novel-buying was reproduced in the collections of individual purchasers, with the temptation to own and to read a form of literature that was by turns 
condemned for being sentimental, salacious or just downright subversive clearly outweighing the purse-lipped imprecations of the critics.

Phillip Doyne, a minor Irish man of letters who died young in 1765, may have been typical in this regard, building up a varied collection of 754 titles that contained many of the key novels of the age as well as most of the major works of the English literary canon: along with two editions of Tristram Shandy and Don Quixote he also owned two copies of Richardson's Clarissa and Fielding's Amelia and Tom Jones. ${ }^{54}$ Similarly, looking at the evidence for the ownership of certain individual novels reinforces the same impression of the genre's widespread presence in personal collections, at least where canonicity could either be assumed or anticipated. Smollett, for example, with his dismissive view of Provençal libraries, would presumably have been far happier with the ubiquitous presence of his own fictional narratives in British book collections. Humphry Clinker, published posthumously in 1771 , was acquired by many collectors, such as by the antiquarian and colonial administrator Sir James Winter Lake, the Huntingdonshire landowner Christopher Beauchamp, the Covent Garden actor John Henderson, the London clergyman Revd Michael Lort, John Simmons of Leicester, the Walker-Heneage family at Compton in Dorset, the Tremayne family at Lamerton in Devon and Revd Andrew Edwards, rector of Great Gressingham in Norfolk, all of them around the end of the eighteenth century. ${ }^{55}$ Lake's collection, meanwhile, like that of the local squire Francis Kirkham of Pinhoe in Devon, was one of many to accommodate Smollett's two other popular novels, Roderick Random of 1748 and Peregrine Pickle from 1751: others who had at least one of these texts in their collections through the second half of the century included the Drake family at Shardeloes in Buckinghamshire, the Treasury clerk William Beldam, General John Fitzwilliam at Richmond, Sir William Beauchamp Proctor MP at his London home in Berkeley Square, the Exeter merchant Thomas Binford, the Sussex attorney Thomas Frewen, the Bristol merchant and Caribbean sugar plantation owner John Pinney at his rented house at Dorchester in Dorset, the great thespian Samuel Foote and the Revd Charles Knollis, Hampshire clergyman and $5^{\text {th }}$ Earl of Banbury. ${ }^{56}$ These, of course, are but the tip of what must have been a very large iceberg, a handful of the contemporary owners of Smollett's work suggested by only a few extant book lists.

The library and the literary imagination

Book-collecting, as we have seen, was integral to the world in which eighteenth-century English literature functioned. Indeed it helped create the market for printed texts, increasingly broad as well as deep, that made authorship and publishing not merely viable but also profitable. Because of the 
central importance of book collections, however, book collections also became a prominent feature of the world as imagined by many contemporary writers, their presence and significance in the lives of their characters regularly brought to the reader's attention. In Cecilia, for example, Burney makes the heroine's purchasing of books a matter for explicit dispute, an impulse that her guardian $\mathrm{Mr}$ Delvile aggressively but unconvincingly contests by arguing for its essentially masculine nature. ${ }^{57}$ Similarly while in Sir Charles Grandison the title-character is able to pass "the greatest part of the day" in seclusion, satisfied with the company of his own books, it is at what is called "the Libraryconference" that a key inter-personal exchange occurs-precisely the same contrast between the solitary and the social that was exploited once again by Anna Maria Mackenzie in Dusseldorf where the house's book collection simultaneously defines the private space where the Count observes "his usual custom of employing the evening" and also serves as the appropriate arena for his crucial plotshaping conversations with others. ${ }^{58}$ Books could also bear profound moral freight in this imaginary world, having impressively weighty implications which spoke of their very real value to contemporaries. In The Mysteries of Udolpho, for example, it is the vulnerable Emily's "little library", her "sweet delight in happier days", that Radcliffe uses to imply her intrinsic virtue. ${ }^{59}$ Even Hurd's Moral and Political Dialogues, the work of one of the age's great real-life bibliophiles, purposely conjures up a library, its shelves stacked with scholarly tomes, as the uniquely suitable setting for a fictional debate about education between those two patron saints of contemporary English philosophy, John Locke and the Earl of Shaftesbury. ${ }^{60}$ The prominence of book collections in the invented world as conceived by British authors clearly underlines their considerable salience in eighteenth-century life as it was lived. In this respect Edward Gibbon, whose Decline and Fall would itself soon become a canonical fixture in so many libraries, was merely representative. As he wrote from Lausanne to his great friend Lord Sheffield in 1787, half-apologising for leaving part of his own collection at his correspondent's home, "Though I can part with land, you find I cannot part with books: the remainder of my library has so long embarrassed your room, that it may now await my presence and final judgment".$^{61}$

\section{NOTES}

\footnotetext{
1 Samuel Johnson: The Idler and Adventurer, (eds.), W.J. Bate, J.M. Bullitt and L.F. Powell (New Haven, CT, 1963), p. 457; James Boswell, The Life of Samuel Johnson (Ware, 1999), p. 782.

2 http://www.library.yale.edu/walpole/about/library history.html [accessed 25/6/2014]; http://www.hurdlibrary.co.uk/ [accessed 25/6/2014]; James Thomson, The Seasons (London, 1746), p. 48.

3 James Boswell, Journal of a Tour to the Hebrides (London, 1785), p. 320; Tobias Smollett, Travels through France and Italy, 2 vols (London, 1776), p. 333.

4 Allen T. Hazen, A Catalogue of Horace Walpole's Library, 3 vols (New Haven, CT, 1969).
} 
5 Farmington, CT: W.S. Lewis Walpole Library: shelfmark 49 3185. For Walpole's hostile annotations, see eg. I, 51, 307. Johnson's contrasting admiration for his fellow-Tory is recorded at The Life of Samuel Johnson, LL.D...., (ed. John Wilson Croker), 5 vols (London, 1831), I, 463.

6 Lady Holland, A Memoir of the Reverend Sydney Smith, 2 vols (New York, 1855), I, 214.

7 Whitehaven: Cumbria Archive Service: D/DA/35.

8 A Catalogue of the Libraries of the Late Dr. Cromwell Mortimer, ... Edmund Pargiter, Esq; and Many Others, Too Tedious to Mention.... ([London], 1753), pp. 595, 597, 375.

9 Kendal: Cumbria Archive Service: WD/K/210, 'Catalogue of the Library at Calgarth Park', 123-4

10 Kendal: Cumbria Archive Service: WD/Ry Box 5, 'Catalogue of Books in the Drawing Room'.

11 David Lundberg and Henry F. May, 'The Enlightened Reader in America', American Quarterly, 28 (1976), 262-71. The broader historical implications of this study of book lists as well as its presumed importance are well seen in the title of the work in which it was subsequently re-printed: P.S. Onuf, (ed.), The New American Nation, 1775-1820, 12 vols. (New York, 1991), XII, 2-33. For a cogent methodological critique, see Mark Spencer, Hume in Colonial and Revolutionary America (Rochester, NY, 2005), pp. 12-16.

12 Sara T. Nalle, 'Literacy and Culture in Early Modern Castile', Past and Present, 125 (1989), 65-96; Miriam Usher Chrisman, Lay Culture, Learned Culture: Books and Social Change in Strasbourg, 1480-1599 (New Haven, CT, 1982); Peter Clark, 'The Ownership of Books in England, 1560-1640: The Example of Some Kentish Townsfolk', in Lawrence Stone, (ed.), Schooling and Society: Studies in the History of Education (Baltimore, MD, 1976), pp. 95-111; Lorna Weatherill, Consumer Behaviour and Material Culture in Britain, 1660-1760 (London, 1988).

13 [James Lackington], Memoirs of the Forty-Five First Years... (London, 1793), p. 76; Chelmsford: Essex RO: D/DU 676/1, Journal of William Barnard of Harlow Bury Farm, 1807-1823, inside back cover.

14 Richard D. Altick, The English Common Reader: A Social History of the Mass Reading Public, 1800-1900 (Chicago, IL, 1957), p. 41.

15 Phillip Connell, "Bibliomania: Book Collecting, Cultural Politics, and the Rise of Literary Heritage in Romantic Britain", Representations, 71 (2000), 24-47.

16 Thomas Frognall Dibdin, The Library Companion (London, 1824), p. 780; Remarks and Collections of Thomas Hearne 1731-1735, (ed.), Rev. H.E. Salter (Oxford, 1921), p. 389; The Works of Lord Chesterfield (New York, 1838), p. 332. The term "bibliophile" also originated in an equivalent French term in use at least as far back as the mid-eighteenth century: see e.g. the phrase "N'envions point de frivoles curiosité à un Bibliophile" in M. I'abbé Desfontaines, L'Esprit de l'Abbé Des Fontaines, ou Reflexions sur Differens Genres de Science et de Literature (Londres [i.e. Paris], 1757), p. 384.

17 Horace Walpole's Correspondence: Volume 33, (ed.), W.S. Lewis (London, 1965), p. 136.

18 Bibliotheca Beauclerkiana. A Catalogue of the Large and Valuable Library of the Late Honourable Topham Beauclerk... (London, [1781]); David Noy, 'The Antiquities Collection of Richard Topham and Topham Beauclerk', Journal of the History of Collections, 24 (2012), 1-9.

19 Arnold Hunt, "The Sale of Richard Heber's Library", in Robin Myers, Michael Harris and Giles Mandelbrote, (eds.), Under the Hammer: Book Auctions Since the Seventeenth Century (New Castle DE, and London, 2001), pp. 143-172; Malcolm Warner, Julia Marciari Alexander and Patrick McCaughey, This Other Eden: Paintings from the Yale Center for British Art (New Haven, CT, 1998), p. 106.

20 Alan Coates, "The Bodleian Library and Its Incunabula", in his (ed.), A Catalogue of Books Printed in the Fifteenth Century Now in the Bodleian Library, Oxford (Oxford, 2005), pp. Ivii-Ixxviii (at p. Ixiv).

21 A Catalogue of Part of the Library of Draper Donynge ([London], 1712), p. 2; Bibliotheca Bernardiana: or, A Catalogue of the Library of the Late Charles Bernard (London, 1711), pp. 105, 131, 173.

22 Vicesimus Knox, Personal Nobility: or, Letters to a Young Nobleman, On the Conduct of His Studies, and the Dignity of the Peerage (London, 1793), p. 184. On the yearning for the most interesting or unusual items see Barbara M. Benedict, "The Curious Attitude in Eighteenth-Century Britain: Observing and Owning", EighteenthCentury Life, 14 (1990), 59-98

23 Catalogue of the Library of the Late Dr. Hamilton, of Lynn.... ([King's Lynn], [1794]).

24 A Catalogue of the Large and Valuable Library of Robert Nesbitt, M.D.,.... ([London], 1761).

25 A Catalogue of the Library of Books, of the Late Learned Dr Abraham Hall.... (London, 1752), pp. 155, 172, 209, 288.

26 A Catalogue Containing the Library of the Late Thomas Baynham.... ([London], 1783).

27 A Catalogue of the Library of That Learned Antiquary, James Wright, Esq.... ([London], 1719), pp. 19, 35-6. 
28 Catalogue of Books, Being the Library of the Late Most Rev. Dr. William Newcombe.... ([Dublin], 1800); Bibliotheca Hickesiana: or, A Catalogue of the Library of the Late Reverend Dr. George Hickes.... ([London], 1716).

29 A Catalogue of the Genuine and Curious Library of the Late Reverend Mr John Jackson.... (Leicester, 1764).

30 A Catalogue of the Entire Library of the Late Learned and Reverend Jeremiah Hunt, D.D.... ([London,], [1744]); A Catalogue of the Library of the Late Reverend and Learned John Gill, D.D.... ([London], 1772); Catalogue of the Library of the Revd Thomas Everson.... ([Thetford], 1749).

31 An Abridgment of Mr. Baxter's History of His Life and Times. With an Account of Many Others ... By Edmund Calamy... (London, 1702), p. 318.

32 A Catalogue of the Genuine and Curious Library of That Learned Antiquary Samuel Gale, Esq.... ([London], 1754); A Catalogue of the Remaining Part of the Valuable Collection of the Late Well Known Antiquary Mr Martin.... ([London], 1774).

33 Sale Catalogues of Eminent Persons: Vol. 4-Architects (ed.) D.J. Watkin (London, 1972), p. 1. In this case the unconfirmed suspicion must be that the catalogue was of only part of Wren's collection.

34 Leeds: Brotherton Library, University of Leeds: MS.500, "Commonplace Book of Mary Cowgill", loose paper.

35 Sale Catalogues of Eminent Persons: Vol. 12-Actors (ed.) James Fullarton Arnott (London, 1975), pp. 238, 257, 294, 302, 309.

36 Jacob Friedrich Bielfeld, Elements of Universal Erudition, tr. W. Hooper, 3 vols (London, 1770), III, 443.

37 James Engell, Forming the Critical Mind: Dryden to Coleridge (Cambridge, MA, and London, 1989); Frank Donoghue, The Fame Machine: Book Reviewing and Eighteenth-Century Literary Careers (Palo Alto, CA, 1996); J.B. Kramnick, Making the English Canon: Print-Capitalism and the Cultural Past, 1700-1770 (Cambridge, 1998); Trevor Ross, The Making of the English Literary Canon from the Middle Ages to the Late Eighteenth Century (Kingston, 1998); Robert Crawford, Devolving English Literature (Oxford, 1992).

38 John Aikin, Letters from a Father to his Son on Various Topics Relative to Literature and the Conduct of Life (London, 1796), p. 290; William Godwin, The Enquirer. Reflections on Education, Manners, and Literature (Dublin, 1797), p. 351.

39 A Catalogue of the Most Esteemed and Useful English Books, Proper to Form a Select Library (London, 1758); Directions for a Proper Choice of Authors to Form a Library... (London, 1766), p. 1.

40 A Catalogue of the Amicable Society's Library, 1812 (Lancaster, 1812); Paul Kaufman, Borrowings from the Bristol Library, 1773-1784: A Unique Record of Reading Vogues (Charlottesville, VA, 1960), pp. 121-38.

41 A Catalogue of a Very Valuable Collection of Books. Containing the Libraries of Dr. James Paston, ... The Rev. Mr. Shipman, ... the Rev. Mr. Mark Purt... and the Late Dr. Richardson (Norwich, 1753).

42 A Catalogue of the Libraries of the Rev. Mr. Batty, ... And of a Person of Quality (London, 1742).

43 Trevor Ross, "Copyright and the Invention of Tradition", Eighteenth-Century Studies, 26 (1992), 1-27; Thomas F. Bonnell, "Bookselling and Canon-Making: The Trade Rivalry over the English Poets, 1776-1783", Studies in Eighteenth-Century Culture, 19 (1989), 53-69.

44 A Catalogue of the Most Esteemed and Useful English Books..., p. 12.

45 A Catalogue of an Elegant Library of Rare and Valuable Books... ([London], 1768).

46 A Catalogue of Books..... of the Late Mr. Anthony Purver.... ([London], 1786).

47 A Catalogue of Books, including the Collection of the Late Mr. John Millan ([London], 1784).

48 John Mason, Self-Knowledge. A Treatise, Shewing the Nature and Benefit of that Important Science... (London, 1778), p. 206.

49 A Catalogue of the Most Esteemed and Useful English Books..., pp. 13-15.

50 Vicesimus Knox, Essays Moral and Literary, 12th edition, 2 vols (London, 1778), I, 68; Samuel Taylor Coleridge, Seven Lectures on Shakespeare and Milton (London, 1856), p. 3; J.T. Taylor, Early Opposition to the English Novel: The Popular Reaction from 1780 to 1830 (New York, 1943).

51 The Lounger (London, 1787), p. 175.

52 Laws for the Regulation of the Literary Society. Leicester ([Leicester], [1790]), p. 11.

53 Catalogue of Books Belonging to the Subscription Library in Shrewsbury... (Shrewsbury, 1812), pp. 104-7; Kaufman, Borrowings from the Bristol Library, p. 121.

54 A Catalogue of Books being the Library of the Late Ingenious Phillip Doyne, Esq... (Dublin, 1766), pp. 1-2, 1516.

55 A Catalogue of the Entire, Genuine, Very Valuable and Rare Library of the Late Sir James Winter Lake.... ([London], 1808), pp. 3, 37; Cambridge: Huntingdonshire Record Office: 1876/28/1 “Catalogue of Books 
Belonging to Mr. C. Beauchamp. 1793"; A Catalogue of the Library of John Henderson, Esq.... ([London], 1786), p. 16; A Catalogue of the Entire and Valuable Library of the Late Rev. Michael Lort... ([London], 1791), p. 127; A Catalogue of Books now Selling... at the Shop of J. Gregory in Leicester ([Leicester], 1779), p. 40; Dorchester: Dorset Record Office: DD/WH6 3095, Catalogue of Compton Library, p. 35; Exeter: Devon Record Office: 1499M, add/Misc.Lit.2, "A Catalogue of Books in the Study Made in AD 1796", fo. 10v; Norwich: Millenium Library: CO18.2EDW, "Catalogue of the Library of the Late Rev Andrew Edwards...", p. 5;

56 Devon Record Office: 312 add7M/F2/11a, "Catalogue of the Books of the late Francis Kirkham of Pinhoe, c. 1774"; Aylesbury: Centre for Buckinghamshire Studies: D.DR 10/50, manuscript catalogue of books-Drake family of Shardeloes, Amersham, fo. 9v; Cambridge: Cambridgeshire Record Office: R58/8/14/5, "A Catalogue of... William Beldam, Esq., deceased...", p. 25; Walpole Library: “A Catalogue of General Fitzwilliam's Books at Richmond in Surrey. Made in July 1787", fo. 11r; Reading: Berkshire Record Office: D/EE E43/2, "An Inventory of the... Books... of Sir William Beauchamp Proctor...", fo. 9r; Devon Record Office: 4508M/F49, "An Account Taken of My Books the 25 $5^{\text {th }}$ October 1768. Thos Binford", fo. 9v; Lewes: East Sussex Record Office: AMS 4948, "An Inventory of the Household Furniture, Linen, China and Books \&c. belonging to Thomas Frewen, Esq.....", p. 38; Bristol: University of Bristol Library, Special Collections: Pinney Miscellaneous Volume 4, "A Catalogue of Books in Mr Harry Pouncey's in Dorchester belonging to me John Pinney... 10 th of July 1764", fo. 13r; $A$

Catalogue of the Well Chosen Library of Books.... of Samuel Foote, Esq.... ([London], [1777]), p. 15; Winchester: Hampshire Record Office: 1 M44/21, "A Catalogue of the Library of the late Earl of Banbury....", fo. 5r.

57 [Fanny Burney], Cecilia, or Memoirs of an Heiress, 5 vols (London, 1782), II, 25-6.

58 [Samuel Richardson], The History of Sir Charles Grandison, 7 vols (London, 1753), I, 204, III, 228; Anna

Maria Mackenzie, Dusseldorf: or, The Fratricide, 3 vols (Dublin, 1798), e.g. II, 53, 61.

59 Ann Radcliffe, The Mysteries of Udolpho, 4 vols (London, 1794), II, 228, 324.

60 Richard Hurd, Moral and Political Dialogues, 3 vols (London, 1788), III, 1-61.

61 Miscellaneous Works of Edward Gibbon, 2 vols (London, 1796), I, 670. 